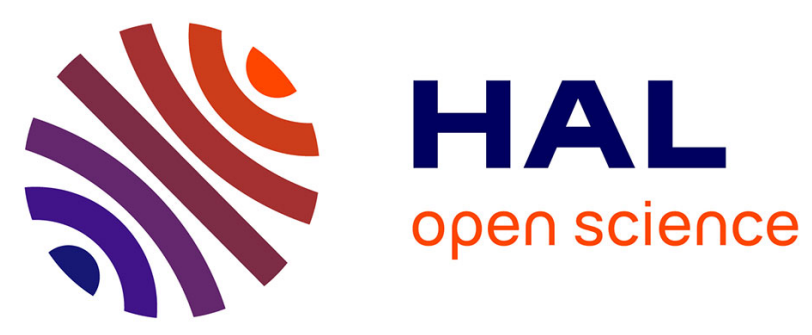

\title{
Novel mosaic variants in two patients with Cornelia de Lange syndrome
}

\author{
Jelena Pozojevic, Ilaria Parenti, Luitgard Graul-Neumann, Sara Ruiz Gil, \\ Erwan Watrin, Kerstin S Wendt, Ralf Werner, Tim M Strom, Gabriele \\ Gillessen-Kaesbach, Frank J Kaiser
}

\section{To cite this version:}

Jelena Pozojevic, Ilaria Parenti, Luitgard Graul-Neumann, Sara Ruiz Gil, Erwan Watrin, et al.. Novel mosaic variants in two patients with Cornelia de Lange syndrome. European Journal of Medical Genetics, 2018, 61 (11), pp.680-684. 10.1016/j.ejmg.2017.11.004 . hal-01812513

\section{HAL Id: hal-01812513 \\ https://hal-univ-rennes1.archives-ouvertes.fr/hal-01812513}

Submitted on 12 Jul 2018

HAL is a multi-disciplinary open access archive for the deposit and dissemination of scientific research documents, whether they are published or not. The documents may come from teaching and research institutions in France or abroad, or from public or private research centers.
L'archive ouverte pluridisciplinaire HAL, est destinée au dépôt et à la diffusion de documents scientifiques de niveau recherche, publiés ou non, émanant des établissements d'enseignement et de recherche français ou étrangers, des laboratoires publics ou privés. 
Novel mosaic variants in two patients with Cornelia de Lange syndrome

Jelena Pozojevic, Ilaria Parenti, Luitgard Graul-Neumann, Sara Ruiz Gil, Erwan

Watrin, Kerstin S. Wendt, Ralf Werner, Tim M. Strom, Gabriele Gillessen-Kaesbach,

Frank J. Kaiser

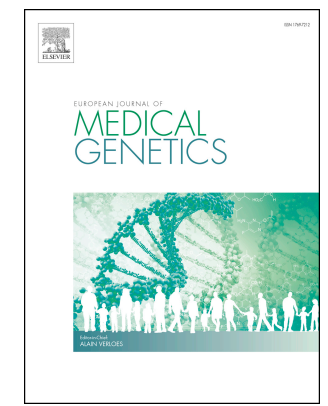

PII:

S1769-7212(17)30498-6

DOI:

10.1016/j.ejmg.2017.11.004

Reference: $\quad$ EJMG 3371

To appear in: European Journal of Medical Genetics

Received Date: 31 July 2017

Revised Date: 11 October 2017

Accepted Date: 12 November 2017

Please cite this article as: J. Pozojevic, I. Parenti, L. Graul-Neumann, S. Ruiz Gil, E. Watrin, K.S. Wendt, R. Werner, T.M. Strom, G. Gillessen-Kaesbach, F.J. Kaiser, Novel mosaic variants in two patients with Cornelia de Lange syndrome, European Journal of Medical Genetics (2017), doi: 10.1016/ j.ejmg.2017.11.004. 


\section{Novel mosaic variants in two patients with Cornelia de Lange syndrome}

Jelena Pozojevic ${ }^{\text {a\# }}$, Ilaria Parenti ${ }^{\text {a\# }}$, Luitgard Graul-Neumann ${ }^{\mathrm{b}}$, Sara Ruiz Gil ${ }^{\mathrm{a}}$, Erwan Watrin ${ }^{\mathrm{c}}$, Kerstin S. Wendt ${ }^{\mathrm{d}}$, Ralf Werner ${ }^{\mathrm{e}}$, Tim M. Strom ${ }^{\mathrm{f}, \mathrm{g}}$, Gabriele Gillessen-Kaesbach ${ }^{\mathrm{h}}$, Frank J. Kaiser $^{\mathrm{a}^{*}}$

a. Section for Functional Genetics, Institute of Human Genetics, Lübeck, Germany

b. Ambulantes Gesundheitszentrum Humangenetik, Charité Universitätsmedizin Berlin, Berlin, Germany

c. Faculté de Médecine, Institut de Génétique et Développement de Rennes, Rennes, France

d. Department of Cell Biology, Erasmus MC, Rotterdam, The Netherlands

e. Division of Experimental Paediatric Endocrinology and Diabetes, Department of Paediatrics and Adolescent Medicine, University of Lübeck, Lübeck, Germany

f. Institute of Human Genetics, Technische Universität München, Munich, Germany

g. Institute of Human Genetics, Helmholtz Zentrum München, Munich, Germany

h. Institute of Human Genetics, Lübeck, Germany

"These authors contributed equally to this work

*corresponding author:

Prof. Dr. Frank J. Kaiser

Section for Functional Genetics

Institute of Human Genetics

Ratzeburger Allee 160

23538 Lübeck

Tel: +49-451-50050411

Fax: +49-451-50050434

email: frank.kaiser@uksh.de 


\section{Abstract}

Cornelia de Lange syndrome (CdLS) is a dominantly inherited developmental disorder caused by mutations in genes that encode for either structural (SMC1A, SMC3, RAD21) or regulatory $(N I P B L, H D A C 8)$ subunits of the cohesin complex. NIPBL represents the major gene of the syndrome and heterozygous mutations can be identified in more than $65 \%$ of patients. Interestingly, large portions of these variants were described as somatic mosaicism and often escape standard molecular diagnostics using lymphocyte DNA.

Here we discuss the role of somatic mosaicism in CdLS and describe two additional patients with NIPBL mosaicism detected by targeted gene panel or exome sequencing. In order to verify the next generation sequencing data, Sanger sequencing or pyrosequencing on DNA extracted from different tissues were applied. None of the pathogenic variants was originally detected by Sanger sequencing on blood DNA.

Patient 1 displays an unusual combination of clinical features: he is cognitively only mildly affected, but shows severe limb reduction defects. The second patient presents with a moderate phenotype. Interestingly, Sanger sequencing analysis on fibroblast DNA did not detect the disease-causing variant previously observed on the same DNA sample by exome sequencing. Subsequent analyses could confirm the variants by Sanger sequencing on buccal mucosa DNA. Notably, this is the first report of a higher mutational load in buccal mucosa than in fibroblast cells of a CdLS patient.

Detection of low-level mosaicism is of utmost importance for an accurate molecular diagnosis and a proper genetic counseling of patients with a clinical diagnosis of CdLS. Next-generation sequencing technologies greatly facilitate the detection of low-level mosaicism, which might otherwise remain undetected by conventional sequencing approaches.

Keywords: Cornelia de Lange syndrome, NIPBL, mosaicism 


\section{Introduction}

Cornelia de Lange syndrome (CdLS, OMIM \#122470, 300590, 610759, 300882, and 614701)

is a rare developmental disorder, clinically and genetically heterogeneous. Besides the distinctive facial features, the syndrome is characterized by growth retardation, cognitive delay with behavioral problems and multiple congenital abnormalities (Kline et al., 2007). To date, approximately $75 \%$ of patients with CdLS carry mutations in structural components (SMC1A, SMC3, RAD21) or regulators (NIPBL, HDAC8) of the cohesin complex (Krantz et al., 2004; Tonkin et al., 2004; Musio et al., 2006; Deardorff et al., 2007; Deardorff et al. 2012a,b). Cohesin plays a fundamental role in the maintenance of genomic stability, since it is involved in the regulation of sister chromatid cohesion, gene expression, DNA repair and chromatin remodeling (Watrin and Peters, 2009; Merkenschlager, 2010; Dorsett and Strom, 2012). In addition to cohesin, variants in other chromatin regulators such as ANKRD11, AFF4, EP300, KMT2A, SETD5 or subunits of the SWI/SNF chromatin-remodeling complex were described in nearly $1 \%$ of patients with CdLS (Woods et al., 2014; Izumi et al., 2015; Yuan et al., 2015; Parenti et al., 2016a; Parenti et al., 2017). Notably, pathogenic variants in all these genes have been described as genetic causes of other developmental syndromes which share phenotypical features with CdLS, thus indicating that chromatin dysregulation is crucial for understanding the pathogenesis of this group of clinically overlapping disorders.

Despite the newly identified causative genes, NIPBL remains the major CdLS gene (Mannini et al.,2013), with disease-causing variants detected in nearly $65 \%$ of CdLS patients. Mutations in NIPBL tend to be associated with more severe phenotypes and with a higher frequency of limb reduction defects in comparison to variants in other cohesin-related genes (Deardorff et al., 2012a,b; Gervasini et al., 2013; Kaiser et al., 2014; Gil-Rodriguez et al., 2015; Parenti et al., 2016b). However, the portion of NIPBL mutations even increases by taking into account the role of somatic mosaicism. Mosaic variants in NIPBL were identified in more than $20 \%$ of 
individuals in a cohort of patients originally reported to be mutation-negative by conventional Sanger sequencing approaches on DNA isolated from blood samples (Huisman et al., 2013). These mosaic variants are of particular interest, because they often escape routine molecular diagnostics, since the sensitivity of Sanger sequencing only allows detection of $15-20 \%$ of aberrant alleles or because of a focused molecular diagnostics restricted to blood DNA samples.

Here we will discuss and expand the crucial role of somatic mosaicism in CdLS and present two additional patients with mosaic disease-causing variants in NIPBL.

\section{Somatic mosaicism}

Somatic mosaicism is a well-known biological phenomenon, occurring not only in humans, but also in other species. It indicates existence of at least two different genotypes in the same individual and can occur for any type of mutation, either at the chromosomal or DNA sequence level. It is difficult to predict clinical consequences of mosaicism, as they depend on the timing of the mutation events, type of mutation, percentage of mutated cells and tissue distribution of the genetic change. Patients with mosaic mutations sometimes show milder phenotypical presentation of the disease, but are also often not distinguishable from those patients with non-mosaic heterozygous variants. In other cases, mosaic individuals appear healthy, without any distinguishable phenotype and mosaicism is revealed only upon molecular testing. Many alterations can occur only in a mosaic form, as the mutation is lethal when present in every cell (Spinner and Conlin, 2014). In favor of this hypothesis speaks the fact that only $\sim 30 \%$ of conceptions result in live births and that majority of pre- and postimplantation pregnancy losses are associated with chromosomal abnormalities in the gametes and embryo (Macklon et al., 2002).

Mosaic mutations can be present in somatic, germinal cells or both, but typically only mutations in the soma have phenotypic consequences and can be detected by current 
sequencing techniques. Germline mosaicism is instead speculated only in the presence of several affected offspring of apparently unaffected parents. However, molecular detection of germline mosaicism is limited by inability to obtain germline DNA, especially in females (Youssoufian and Pyeritz, 2002; Freed et al., 2014).

The first mosaic chromosomal abnormality was reported in 1960 (Hirschhorn et al., 1960), while the first suggestion of chromosomal mosaicism in patients with CdLS was reported in 1965 (Payne and Maeda, 1965). In this report, translocations and deletions were visible only in some of the analyzed karyotypes of patient cells, while the other cells appeared normal. The first patient with a mosaic mutation in NIPBL was reported by Castronovo and colleagues (Castronovo et al., 2010). Since then, somatic mosaicism has been described for all five CdLS genes, though the vast majority affects NIPBL (Hoppman-Chaney et al., 2012; Slavin et al., 2012; Huisman et al., 2013; Braunholz et al., 2015; Ansari et al., 2014; Gil-Rodriguez et al., 2015; Parenti et al., 2016b). The phenotypical spectrum of patients with mosaic variants in $N I P B L$ is very broad, ranging from mildly to severely affected individuals. Therefore, distinct clinical features indicating somatic mosaicism have not been described so far.

Interestingly, very low levels of somatic mosaicism for some of the CdLS genes have been reported also in few unaffected parents of patients with CdLS: Slavin and colleagues described low-levels of a mosaic mutation in SMCIA in the blood DNA of an unaffected father of two affected sisters (Slavin et al., 2012). In addition, our group recently reported an unaffected mother of two siblings with CdLS, mosaic for an HDAC8 variant in her urine (19\%) and blood DNA (2\%) (Parenti et al., 2016b). Few cases with gonadal NIPBL mosaicism have also been described (Niu et al., 2006; Weichert et al., 2011; Slavin et al., 2012). However, a recent study showed that a portion of de novo mutations presumed to be germline actually either occurred post-zygotically in the embryo or were inherited from the mother or father with low-level mosaicism (Acuna-Hidalgo et al., 2015). 
Here we report two patients with the clinical diagnosis of CdLS, who were found to be negative for pathogenic variants in the five CdLS genes by conventional Sanger sequencing approaches on blood DNA. The disease-causing variants were subsequently identified by means of next generation sequencing techniques.

\section{Patients}

Patient 1 (Fig. 1a) is a 32 years old German male being the first child born to healthy parents. The pregnancy was uneventful and he was born after 42 weeks of gestation. Birth length was $48 \mathrm{~cm}$ (-2.25 SD), birth weight $3170 \mathrm{~g}$ (-1.35SD), occipital frontal circumference (OFC) 32 cm (-2.93 SD), and Apgar score were 6/9/10, respectively. He has not displayed any feeding difficulties. The patient presents with facial features typical for CdLS, namely synophrys, long eyelashes, depressed nasal bridge, upturned nose, thin upper lip, low set ears and low anterior hairline. He also presents with split hand deformity on the left hand and ulnar oligodactyly with missing fifth finger on the right hand. His left leg is $1.3 \mathrm{~cm}$ shorter than the right leg, due to pronounced hip dysplasia, corrected by orthopedic shoes. He was able to sit alone at the age of 9 months and to walk independently at the age of 20 months. He spoke his first words when he was almost one year old and he is able to communicate by using only a few words, but he is not able to produce longer sentences. The patient is capable to write and read with certain limitations, to swim, ride a bike, solve puzzles and to use modern media such as a digital camera. He is able to take care of himself and works in a carpenter's shop. He occasionally suffers from headaches and has excessive amount of saliva. At the current age (32 years), the patient's height is $156 \mathrm{~cm}(-0.8 \mathrm{SD})$, his weight is $40 \mathrm{~kg}$ ($0.3 \mathrm{SD})$ and his $\mathrm{OFC}$ is $52.8 \mathrm{~cm}(-2.4 \mathrm{SD})$.

Buccal DNA of the patient was analyzed by targeted CdLS-panel, which was performed on the Personal Genome Machine (Ion Torrent PGM, Life Technologies, Darmstadt, Germany) 
as previously described (Braunholz et al., 2015). By this, we identified a nonsense mutation in NIPBL (RefSeq NM_133433), namely c.4399A>T; p.(Lys1467*), in 30\% of the sequencing reads. The variant was confirmed by Sanger sequencing on buccal DNA, as well as on DNA obtained from epithelial urine cells, whereas it was not detectable on blood DNA (Fig. 1c). Parents were not available for testing, but the variant was not present in the Genome Aggregation Database (gnomAD).

Patient 2 (Fig. 1b) is a female, the only child born to a German mother and a Syrian father. Family history comprises Lupus erythematosus and vitamin D deficiency. Additionally, the mother had terminated a previous pregnancy due to the presence of trisomy 21 . The pregnancy of the index patient was unremarkable, albeit prenatal brachycephaly was described. The delivery was vacuum-assisted, birth weight was 3140 g (-0.79 SD), birth length was $50 \mathrm{~cm}(-0.77 \mathrm{SD})$, occipital frontal circumference (OFC) was $35 \mathrm{~cm}$ (0.08 SD), Apgar scores were 9/9/10 and $\mathrm{pH}$ of umbilical arteries was 7.18. The patient showed early feeding difficulties, which required a high-caloric diet. She was able to walk independently at 18 months. She was diagnosed with patent foramen ovale with right to left shunt and X-ray of her hands showed shortening of the first metacarpal. She presents with a friendly behavior. Array-CGH, MLPA for NIPBL and Sanger sequencing on blood DNA for NIPBL, SMC1A, $R A D 21$ and HDAC8 could not detect any disease-causing variant. For this reason, the patient was selected to undergo a trio-based exome sequencing analysis, which was performed on the HiSeq 2500 system (Illumina, San Diego, CA, USA) as previously described (Parenti et al., 2017). This analysis, which was performed on DNA extracted from fibroblasts, led to the identification of the de novo missense mutation c.5483G >A, p. (Arg1828Gln) in NIPBL in $15 \%$ of the sequencing reads. The variant was not present in the Genome Aggregation Database (gnomAD). Interestingly, we were not able to confirm this mutation by Sanger sequencing neither on blood nor on fibroblast DNA (Fig. 1d). However, the electropherogram performed on fibroblasts displayed a small mutant peak underneath the wild type base. As 
next, we performed pyrosequencing on blood and fibroblast DNA of the patient. The ratio between the mutant and the wild type allele was found to be 14:86 on fibroblasts DNA and 2:98 on blood DNA (Fig. 1e), hence explaining why the mutation was not detected by Sanger sequencing. We subsequently obtained DNA from a third tissue, namely buccal mucosa. In this tissue, the pathogenic-variant could be detected by conventional Sanger sequencing (Fig. 1d), and pyrosequencing analysis revealed a mutant:wild type ratio of 17:83 (Fig. 1e). We previously demonstrated that fibroblasts represent the best source of DNA for mutation detection through Sanger sequencing (Braunholz et al., 2015). Thus, our patient represents the first case in which cells from buccal mucosa show a higher percentage of the mutant allele than fibroblasts.

\section{Discussion}

Somatic mosaicism has been proven to play a very important role in the pathogenesis of several disorders (Freed et al., 2014). However, patients with mosaic mutations show variable phenotypes and it is not possible to predict in advance, based on clinical features, if a mutation will be found in a mosaic state or not. Thus, there is usually no clear correlation between the mutation load and the phenotype. For instance, severe limb reduction defects as seen in patient 1 are restricted to CdLS patients with variants in NIPBL and almost exclusively caused by truncating variants or null alleles. While the severe malformation of the left arm is in agreement with the genotype, a mild cognitive impairment as seen in patient 1 is rather unique and has never been reported in a patient with this type of NIPBL mutation. Based on our findings that indicate absence of the mutation in blood and only $30 \%$ in buccal mucosa DNA, it is tempting to speculate that some other tissues, especially neuronal tissues, might show only small portions of the variant, which may explain the mild cognitive impairment. In a previous report another mildly affected CdLS patient with severe limb defects was reported as negative for a disease-causing variant in NIPBL using DNA from 
lymphocytes [Bhuiyan et al., 2006]. Based on our findings it is tempting to speculate if this patient is also mosaic for a disease-causing variant in NIPBL.

Blood leukocytes have been the gold standard material for molecular analysis for decades. Nevertheless, mosaic mutations are frequently not detected in these samples, meaning that DNA of additional tissues is required for a comprehensive and proper molecular testing, especially of those patients with clear clinical diagnosis, but negative results. Previously, we have described three patients with somatic variants in NIPBL identified by conventional Sanger sequencing approaches on DNA extracted from fibroblast cells, but not on DNA from buccal mucosa or blood cells (Braunholz et al., 2015). Therefore, fibroblasts from skin biopsies were recommended as the most suitable tissue for molecular diagnostics. In contrast to our previous report, here we describe a somatic mosaicism that was detected by conventional Sanger sequencing on DNA from buccal mucosa, but not detected using fibroblast DNA. However, highly sensitive pyrosequencing approaches could identify the pathogenic variant in DNA samples of both tissues. Based on these findings, we recommend the use of sensitive next generation sequencing approaches with high numbers of sequencing reads that should not be restricted to DNA from blood samples. Only the combination of sensitive sequencing technologies and DNA from sources other than blood allow an appropriate molecular diagnostics of patients with clinical diagnosis of CdLS.

The identification of low-level mosaicism is of great importance for an accurate diagnosis and proper genetic counseling. Therefore, we strongly recommend integration of modern and highly sensitive sequencing techniques into the routine molecular diagnostics of CdLS. With increasing costs and availability of next generation sequencing technologies, we believe that high-coverage exome sequencing will be the most efficient and most suitable technology for appropriate molecular diagnostics of CdLS. Furthermore, to confirm and quantify putative mosaic variants represented by small numbers of total sequencing reads, we suggest additional sensitive targeted sequencing technologies such as pyrosequencing. 
Acknowledgements: The authors are grateful to the patients and their families for generously donating samples and clinical information. This work was funded by the German Federal Ministry of Education and Research (BMBF) (CHROMATIN-Net: to F.J.K. and G.G.K.), by E-Rare-2 TARGET-CdLS (to F.J.K, K.W. and E.W.) and by the Medical Faculty of the University of Lübeck (J09-2017 to I.P.).

Figure titles and legends: Figure 1. Phenotype of the patients and sequencing results. (a)

Phenotype of patient 1, with a detail of the anomalies of the upper limbs. (b) Facial features of patient 2 , including a detail of the small and widely spaced teeth. To be noted the presence of hirsutism.(c-d) Sanger sequencing of DNA obtained from different tissues ofpatient 1 (c) and patient 2 (d). (e) Pyrosequencing results from different tissues of patient 2.

\section{References:}

1) Acuna-Hidalgo, R., Bo, T., Kwint, M.P., Van De Vorst, M., Pinelli, M., Veltman, J.A., Hoischen, A., Vissers, L.E.L.M., Gilissen, C., 2015. Post-zygotic Point Mutations Are an Underrecognized Source of de Novo Genomic Variation. Am. J. Hum. Genet. 97, 67-74. doi:10.1016/j.ajhg.2015.05.008

2) Ansari, M., Poke, G., Ferry, Q., Williamson, K., Aldridge, R., Meynert, A.M., Bengani, H., Chan, C.Y., Kayserili, H., Avci, Ş., Hennekam, R.C.M., Lampe, A.K., Redeker, E., Homfray, T., Ross, A., Falkenberg Smeland, M., Mansour, S., Parker, M.J., Cook, J.A., Splitt, M., Fisher, R.B., Fryer, A., Magee, A.C., Wilkie, A., Barnicoat, A., Brady, A.F., Cooper, N.S., Mercer, C., Deshpande, C., Bennett, C.P., Pilz, D.T., Ruddy, D., Cilliers, D., Johnson, D.S., Josifova, D., Rosser, E., Thompson, E.M., Wakeling, E., Kinning, E., Stewart, F., Flinter, F., Girisha, K.M., Cox, H., Firth, H. V, Kingston, H., Wee, J.S., Hurst, J.A., Clayton-Smith, J., Tolmie, J., Vogt, J., Tatton-Brown, K., Chandler, K., Prescott, K., Wilson, L., Behnam, M., McEntagart, M., Davidson, R., Lynch, S.-A., Sisodiya, S., Mehta, S.G., McKee, S.A., Mohammed, S., Holden, S., Park, S.-M., Holder, S.E., Harrison, V., McConnell, V., Lam, W.K., Green, A.J., Donnai, D., Bitner-Glindzicz, M., Donnelly, D.E., Nellåker, C., Taylor, M.S., FitzPatrick, D.R., 2014. Genetic heterogeneity in Cornelia de Lange syndrome (CdLS) and CdLS-like phenotypes with observed and predicted levels of mosaicism. J. Med. Genet. 51, 659-668. doi:10.1136/jmedgenet-2014-102573 
3) Bhuiyan, Z.A., Klein M., Hammond P., van Haeringen A., Mannens M.M., Van Berckelaer-Onnes I., Hennekam R.C., 2006. Genotype-phenotype correlations of 39 patients with Cornelia De Lange syndrome: the Dutch experience. J. Med. Genet. 43, 568-575. doi:10.1136/jmg.2005.038240

4) Braunholz, D., Obieglo, C., Parenti, I., Pozojevic, J., Eckhold, J., Reiz, B., Brænne, I., Wendt, K.S., Watrin, E., Vodopiutz, J., Rieder, H., Gillessen-Kaesbach, G., Kaiser, F.J., 2015. Hidden mutations in Cornelia de Lange syndrome limitations of Sanger sequencing in molecular diagnostics. Hum. Mutat. 36, 26-29. doi:10.1002/humu.22685

5) Castronovo, P., Delahaye-Duriez, A., Gervasini, C., Azzollini, J., Minier, F., Russo, S., Masciadri, M., Selicorni, A., Verloes, A., Larizza, L., 2010. Somatic mosaicism in Cornelia de Lange syndrome: A further contributor to the wide clinical expressivity? Clin. Genet. 78, 560-564. doi:10.1111/j.1399-0004.2010.01408.x

6) Deardorff, M.A., Kaur, M., Yaeger, D., Rampuria, A., Korolev, S., Pie, J., GilRodríguez, C., Arnedo, M., Loeys, B., Kline, A.D., Wilson, M., Lillquist, K., Siu, V., Ramos, F.J., Musio, A., Jackson, L.S., Dorsett, D., Krantz, I.D., 2007. Mutations in Cohesin Complex Members SMC3 and SMC1A Cause a Mild Variant of Cornelia de Lange Syndrome with Predominant Mental Retardation. Am. J. Hum. Genet. 80, 485494. doi:10.1086/511888

7) Deardorff, M.A., Bando, M., Nakato, R., Watrin, E., Itoh, T., Minamino, M., Saitoh, K., Komata, M., Katou, Y., Clark, D., Cole, K.E., De Baere, E., Decroos, C., Di Donato, N., Ernst, S., Francey, L.J., Gyftodimou, Y., Hirashima, K., Hullings, M., Ishikawa, Y., Jaulin, C., Kaur, M., Kiyono, T., Lombardi, P.M., Magnaghi-Jaulin, L., Mortier, G.R., Nozaki, N., Petersen, M.B., Seimiya, H., Siu, V.M., Suzuki, Y., Takagaki, K., Wilde, J.J., Willems, P.J., Prigent, C., Gillessen-Kaesbach, G., Christianson, D.W., Kaiser, F.J., Jackson, L.G., Hirota, T., Krantz, I.D., Shirahige, K., 2012a. HDAC8 mutations in Cornelia de Lange syndrome affect the cohesin acetylation cycle. Nature 489, 313-317. doi:10.1038/nature11316

8) Deardorff, M.A., Wilde, J.J., Albrecht, M., Dickinson, E., Tennstedt, S., Braunholz, D., Mönnich, M., Yan, Y., Xu, W., Gil-Rodríguez, M.C., Clark, D., Hakonarson, H., Halbach, S., Michelis, L.D., Rampuria, A., Rossier, E., Spranger, S., Van Maldergem, L., Lynch, S.A., Gillessen-Kaesbach, G., Lüdecke, H.J., Ramsay, R.G., McKay, M.J., Krantz, I.D., Xu, H., Horsfield, J.A., Kaiser, F.J., 2012b. RAD21 mutations cause a human cohesinopathy. Am. J. Hum. Genet. 90, 1014-1027. doi:10.1016/j.ajhg.2012.04.019

9) Dorsett, D., Ström, L., 2012. The ancient and evolving roles of cohesin in gene expression and DNA repair. Curr. Biol. 22, 240-250. doi:10.1016/j.cub.2012.02.046

10) Freed, D., Stevens, E.L., Pevsner, J., 2014. Somatic mosaicism in the human genome. Genes (Basel). 5, 1064-1094. doi:10.3390/genes5041064

11) Gervasini, C., Parenti, I., Picinelli, C., Azzollini, J., Masciadri, M., Cereda, A., Selicorni, A., Russo, S., Finelli, P., Larizza, L., 2013. Molecular characterization of a mosaic NIPBL deletion in a Cornelia de Lange patient with severe phenotype. Eur. J. Med. Genet. 56, 138-143. doi:10.1016/j.ejmg.2012.12.009

12) Gil-Rodríguez, M.C., Deardorff, M.A., Ansari, M., Tan, C.A., Parenti, I., BaqueroMontoya, C., Ousager, L.B., Puisac, B., Hernández-Marcos, M., Teresa-Rodrigo, M.E., Marcos-Alcalde, I., Wesselink, J.J., Lusa-Bernal, S., Bijlsma, E.K., Braunholz, D., Bueno-Martinez, I., Clark, D., Cooper, N.S., Curry, C.J., Fisher, R., Fryer, A., Ganesh, J., Gervasini, C., Gillessen-Kaesbach, G., Guo, Y., Hakonarson, H., Hopkin, R.J., Kaur, M., Keating, B.J., Kibaek, M., Kinning, E., Kleefstra, T., Kline, A.D., Kuchinskaya, E., Larizza, L., Li, Y.R., Liu, X., Mariani, M., Picker, J.D., Pié, Á., Pozojevic, J., Queralt, E., Richer, J., Roeder, E., Sinha, A., Scott, R.H., So, J., Wusik, 
K.A., Wilson, L., Zhang, J., Gómez-Puertas, P., Casale, C.H., Ström, L., Selicorni, A., Ramos, F.J., Jackson, L.G., Krantz, I.D., Das, S., Hennekam, R.C.M., Kaiser, F.J., Fitzpatrick, D.R., Pié, J., 2015. De novo heterozygous mutations in SMC3 cause a range of cornelia de lange syndrome-overlapping phenotypes. Hum. Mutat. 36, 454462. doi:10.1002/humu.22761

13) Hirschhorn, K., Decker, W.H., Cooper, H.L., 1960. Human Intersex with Chromosome Mosaicism of Type XY/XO. N. Engl. J. Med. 263, 1044-1048. doi:10.1056/NEJM196011242632102

14) Hoppman-Chaney, N., Jang, J.S., Jen, J., Babovic-Vuksanovic, D., Hodge, J.C., 2012. In-frame multi-exon deletion of SMC1A in a severely affected female with Cornelia de Lange Syndrome. Am. J. Med. Genet. Part A 158 A, 193-198. doi:10.1002/ajmg.a.34360

15) Huisman, S.A., Redeker, E.J.W., Maas, S.M., Mannens, M.M., Hennekam, R.C.M., 2013. High rate of mosaicism in individuals with Cornelia de Lange syndrome. J. Med. Genet. 50, 339-344. doi:10.1136/jmedgenet-2012-101477

16) Izumi, K., Nakato, R., Zhang, Z., Edmondson, A.C., Noon, S., Dulik, M.C., Rajagopalan, R., Venditti, C.P., Gripp, K., Samanich, J., Zackai, E.H., Deardorff, M.A., Clark, D., Allen, J.L., Dorsett, D., Misulovin, Z., Komata, M., Bando, M., Kaur, M., Katou, Y., Shirahige, K., Krantz, I.D., 2015. Germline gain-of-function mutations in AFF4 cause a developmental syndrome functionally linking the super elongation complex and cohesin. Nat. Genet. 47, 338-344. doi:10.1038/ng.3229

17) Kaiser, F.J., Ansari, M., Braunholz, D., Gil-Rodríguez, M.C., Decroos, C., Wilde, J.J., Fincher, C.T., Kaur, M., Bando, M., Amor, D.J., Atwal, P.S., Bahlo, M., Bowman, C.M., Bradley, J.J., Brunner, H.G., Clark, D., Campo, M. Del, Di Donato, N., Diakumis, P., Dubbs, H., Dyment, D.A., Eckhold, J., Ernst, S., Ferreira, J.C., Francey, L.J., Gehlken, U., Guillén-Navarro, E., Gyftodimou, Y., Hall, B.D., Hennekam, R., Hudgins, L., Hullings, M., Hunter, J.M., Yntema, H., Innes, A.M., Kline, A.D., Krumina, Z., Lee, H., Leppig, K., Lynch, S.A., Mallozzi, M.B., Mannini, L., Mckee, S., Mehta, S.G., Micule, I., Consortium, C.R.C., Mohammed, S., Moran, E., Mortier, G.R., Moser, J.A.S., Noon, S.E., Nozaki, N., Nunes, L., Pappas, J.G., Penney, L.S., Pérez-Aytés, A., Petersen, M.B., Puisac, B., Revencu, N., Roeder, E., Saitta, S., Scheuerle, A.E., Schindeler, K.L., Siu, V.M., Stark, Z., Strom, S.P., Thiese, H., Vater, I., Willems, P., Williamson, K., Wilson, L.C., Hakonarson, H., Quintero-Rivera, F., Wierzba, J., Musio, A., Gillessen-Kaesbach, G., Ramos, F.J., Jackson, L.G., Shirahige, K., Pié, J., Christianson, D.W., Krantz, I.D., Fitzpatrick, D.R., Deardorff, M.A., 2014. Loss-of-function HDAC8 mutations cause a phenotypic spectrum of Cornelia de Lange syndrome-like features, ocular hypertelorism, large fontanelle and X-linked inheritance. Hum. Mol. Genet. 23, 2888-2900. doi:10.1093/hmg/ddu002

18) Kline, A.D., Krantz, I.D., Sommer, A., Kliewer, M., Jackson, L.G., FitzPatrick, D.R., Levin, A. V., Selicorni, A., 2007. Cornelia de Lange syndrome: Clinical review, diagnostic and scoring systems, and anticipatory guidance. Am. J. Med. Genet. Part A. doi:10.1002/ajmg.a.31757

19) Krantz, I.D., McCallum, J., DeScipio, C., Kaur, M., Gillis, L.A., Yaeger, D., Jukofsky, L., Wasserman, N., Bottani, A., Morris, C.A., Nowaczyk, M.J., Toriello, H., Bamshad, M.J., Carey, J.C., Rappaport, E., Kawauchi, S., Lander, A.D., Calof, A.L., Li, H.H., Devoto, M., Jackson, L.G., 2004. Cornelia de Lange syndrome is caused by mutations in NIPBL, the human homolog of Drosophila melanogaster Nipped-B. Nat Genet 36, 631-635. doi:10.1038/ng1364

20) Macklon, N.S., Geraedts, J.P.M., Fauser, B.C.J.M., 2002. Conception to ongoing pregnancy: The "black box" of early pregnancy loss. Hum. Reprod. Update 8, 333343. doi:10.1093/humupd/8.4.333 
21) Mannini, L., Cucco, F., Quarantotti, V., Krantz, I.D., Musio, A., 2013. Mutation Spectrum and Genotype-Phenotype Correlation in Cornelia de Lange Syndrome. Hum. Mutat. 34, 1589-1596. doi:10.1002/humu.22430

22) Merkenschlager, M., 2010. Cohesin: A global player in chromosome biology with local ties to gene regulation. Curr. Opin. Genet. Dev. 20, 555-561. doi:10.1016/j.gde.2010.05.007

23) Musio, A., Selicorni, A., Focarelli, M.L., Gervasini, C., Milani, D., Russo, S., Vezzoni, P., Larizza, L., 2006. X-linked Cornelia de Lange syndrome owing to SMC1L1 mutations. Nat. Genet. 38, 528-530. doi:10.1038/ng1779

24) Niu, D.-M., Huang, J.-Y., Li, H.-Y., Liu, K.-M., Wang, S.-T., Chen, Y.-J., Udaka, T., Izumi, K., Kosaki, K., 2006. Paternal gonadal mosaicism of NIPBL mutation in a father of siblings with Cornelia de Lange syndrome. Prenat. Diagn. 26, 1054-1057. doi:10.1002/pd.1554

25) Parenti, I., Gervasini, C., Pozojevic, J., Graul-Neumann, L., Azzollini, J., Braunholz, D., Watrin, E., Wendt, K.S., Cereda, A., Cittaro, D., Gillessen-Kaesbach, G., Lazarevic, D., Mariani, M., Russo, S., Werner, R., Krawitz, P., Larizza, L., Selicorni, A., Kaiser, F.J., 2016a. Broadening of cohesinopathies: Exome sequencing identifies mutations in ANKRD11 in two patients with Cornelia de Lange-overlapping phenotype. Clin. Genet. 89, 74-81. doi:10.1111/cge.12564

26) Parenti, I., Gervasini, C., Pozojevic, J., Wendt, K.S., Watrin, E., Azzollini, J., Braunholz, D., Buiting, K., Cereda, A., Engels, H., Garavelli, L., Glazar, R., Graffmann, B., Larizza, L., Lüdecke, H.J., Mariani, M., Masciadri, M., Pié, J., Ramos, F.J., Russo, S., Selicorni, A., Stefanova, M., Strom, T.M., Werner, R., Wierzba, J., Zampino, G., Gillessen-Kaesbach, G., Wieczorek, D., Kaiser, F.J., 2016b. Expanding the clinical spectrum of the "HDAC8-phenotype" - implications for molecular diagnostics, counseling and risk prediction. Clin. Genet. 89, 564-573. doi:10.1111/cge. 12717

27) Parenti, I., Teresa-Rodrigo, M.E., Pozojevic, J., Ruiz Gil, S., Bader, I., Braunholz, D., Bramswig, N.C., Gervasini, C., Larizza, L., Pfeiffer, L., Ozkinay, F., Ramos, F., Reiz, B., Rittinger, O., Strom, T.M., Watrin, E., Wendt, K., Wieczorek, D., Wollnik, B., Baquero-Montoya, C., Pié, J., Deardorff, M.A., Gillessen-Kaesbach, G., Kaiser, F.J., 2017. Mutations in chromatin regulators functionally link Cornelia de Lange syndrome and clinically overlapping phenotypes. Hum. Genet. 136, 307-320. doi:10.1007/s00439-017-1758-y

28) Payne, H.W., Maeda, W.K., 1965. The Cornelia de Lange syndrome: clinical and cytogenetic interpretations. Can Med Assoc J 93, 577-586.

29) Slavin, T.P., Lazebnik, N., Clark, D.M., Vengoechea, J., Cohen, L., Kaur, M., Konczal, L., Crowe, C.A., Corteville, J.E., Nowaczyk, M.J., Byrne, J.L., Jackson, L.G., Krantz, I.D., 2012. Germline mosaicism in Cornelia de Lange syndrome. Am. J. Med. Genet. Part A 158 A, 1481-1485. doi:10.1002/ajmg.a.35381

30) Spinner, N.B., Conlin, L.K., 2014. Mosaicism and clinical genetics. Am. J. Med. Genet. Part C Semin. Med. Genet. 166, 397-405. doi:10.1002/ajmg.c.31421

31) Tonkin, E.T., Wang, T.-J., Lisgo, S., Bamshad, M.J., Strachan, T., 2004. NIPBL, encoding a homolog of fungal Scc2-type sister chromatid cohesion proteins and fly Nipped-B, is mutated in Cornelia de Lange syndrome. Nat. Genet. 36, 636-641. doi:10.1038/ng1363

32) Watrin, E., Peters, J.-M., 2009. The cohesin complex is required for the DNA damageinduced G2/M checkpoint in mammalian cells. EMBO J. 28, 2625-2635. doi:10.1038/emboj.2009.202

33) Weichert, J., Schröer, A., Beyer, D.A., Gillessen-Kaesbach, G., Stefanova, I., 2011. Cornelia de Lange syndrome: antenatal diagnosis in two consecutive pregnancies due 
to rare gonadal mosaicism of NIPBL gene mutation. J. Matern. Fetal. Neonatal Med. 24, 978-82. doi:10.3109/14767058.2010.531312

34) Woods, S.A., Robinson, H.B., Kohler, L.J., Agamanolis, D., Sterbenz, G., Khalifa, M., 2014. Exome sequencing identifies a novel EP300 frame shift mutation in a patient with features that overlap cornelia de lange syndrome. Am. J. Med. Genet. Part A 164, 251-258. doi:10.1002/ajmg.a.36237

35) Youssoufian, H., Pyeritz, R.E., 2002. Mechanisms and consequences of somatic mosaicism in humans. Nat. Rev. Genet. 3, 748-758. doi:10.1038/nrg906

36) Yuan, B., Pehlivan, D., Karaca, E., Patel, N., Charng, W.L., Gambin, T., GonzagaJauregui, C., Sutton, V.R., Yesil, G., Bozdogan, S.T., Tos, T., Koparir, A., Koparir, E., Beck, C.R., Gu, S., Aslan, H., Yuregir, O.O., Rubeaan, K. Al, Alnaqeb, D., Alshammari, M.J., Bayram, Y., Atik, M.M., Aydin, H., Geckinli, B.B., Seven, M., Ulucan, H., Fenercioglu, E., Ozen, M., Jhangiani, S., Muzny, D.M., Boerwinkle, E., Tuysuz, B., Alkuraya, F.S., Gibbs, R.A., Lupski, J.R., 2015. Global transcriptional disturbances underlie Cornelia de Lange syndrome and related phenotypes. J. Clin. Invest. 125, 636-651. doi:10.1172/JCI77435 
a

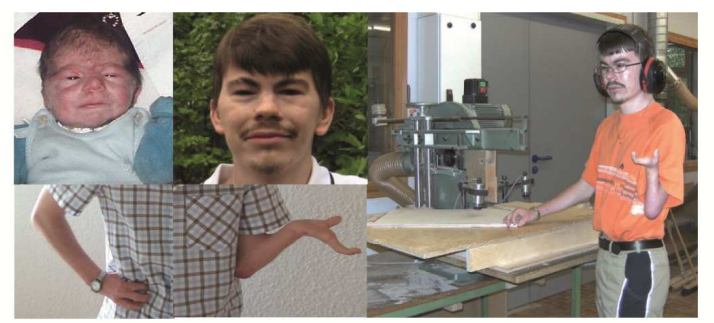

c

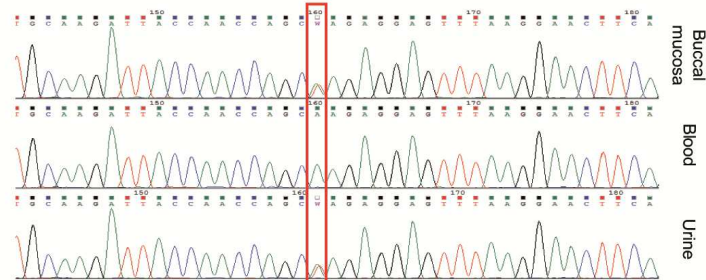

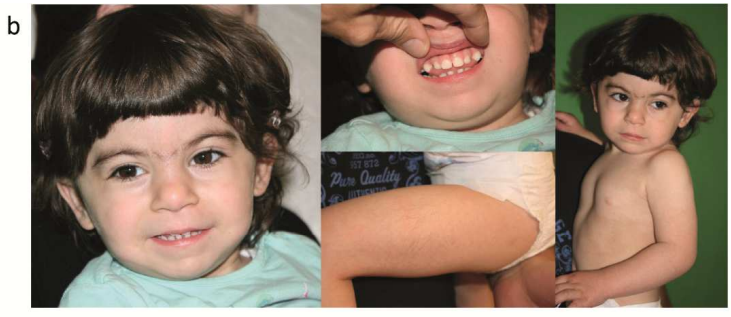

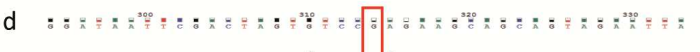

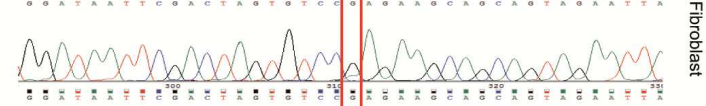

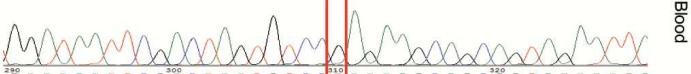

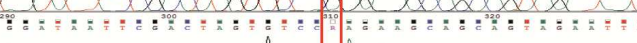

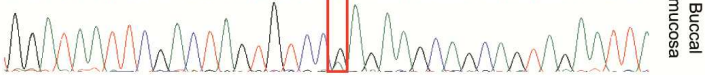

e
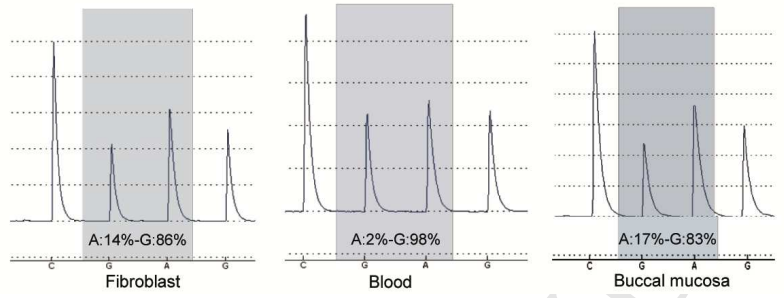